Jurnal Inspirasi Pendidikan
Vol. 10 No. 2 Tahun $2020 \mid$ Hal. $85-95$

\title{
Proses Berpikir Aljabar Siswa SMP Ditinjau dari Kemampuan Akademik Matematika dan Gender
}

\author{
Ridha Chairunisa $^{\text {a, } 1}$, Maimunah ${ }^{\text {b, 2*}}$, Yenita Roza ${ }^{\text {c, } 3}$ \\ a,b,c Pendidikan Matematika Pascasarjana Universitas Riau, Indonesia \\ ridha.chairunisa7001@grad.unri.ac.id; ${ }^{2}$ maimunah@lecturer.unri.ac.id *33enita.roza@lecturer.unri.ac.id \\ *korespondensi penulis
}

\section{Informasi artikel}

Received :

April 04, 2020.

Revised :

May 11,2020

Publish :

August 31, 2020.

Kata kunci:

Proses Berpikir

Aljabar

Gender

Kemampuan

Akademik

Matematika

\begin{abstract}
ABSTRAK
Tujuan dari penelitian ini yaitu untuk mengetahui proses berpikir aljabar siswa pada materi segi empat yang ditinjau dari kemampuan matematika dan gender. Metode penelitian ini adalah kualitatif deskriptif. Subjek penelitian ini adalah 9 siswa perempuan dan 9 siswa laki-laki dengan kemampuan matematika tinggi, sedang dan rendah yang berada dikelas IX. Instrumen dalam penelitian ini yaitu tes dan wawancara. Hasil dari penelitian ini menunjukkan bahwa siswa perempuan kemampuan tinggi sudah berpikir aljabar. Siswa laki-laki kemampuan tinggi sudah berpikir aljabar namun pada indikator menyimpulkan dan memeriksa kembali belum terpenuhi. Siswa perempuan kemampuan sedang sudah berpikir aljabar namun terdapat kecerobohan dalam perhitungan. Siswa laki-laki kemampuan sedang sudah mulai berpikir aljabar namun pada indikator menafsirkan dan menerapkan temuan matematika belum terpenuhi. Siswa perempuan dan laki-laki kemampuan rendah belum berpikir aljabar karena seluruh indikator tidak terpenuhi. Penyebab dari siswa belum berpikir aljabar ini adalah siswa tidak memahami konsep aljabar sehingga dalam memecahkan masalah matematika siswa tidak mampu. Siswa perempuan dan laki-laki kemampuan tinggi dan sedang yang sudah berpikir aljabar mampu dalam memecahkan masalah matematika. Namun siswa perempuan dan laki-laki kemampuan rendah belum berpikir aljabar sehingga belum mampu menyelesaikan masalah.
\end{abstract}

\begin{abstract}
The purpose of this research is to know algebra thinking process of students in rectangular material reviewed from Mathematics ability and gender. The method of this research was qualitative descriptive. The research subjects were 9 female students and 9 male students of grade IX with high, medium, and low Mathematics ability. The research instruments were test and interview. The research results show that female students with high ability have algebra thinking. Male students with high ability have algebra thinking but indicator of concluding and rechecking was not fulfilled yet. Female students with medium ability have algebra thinking but there was carelessness in the calculation. Male students with medium ability have started to thought algebra but at indicator of interpreting and applying Mathematics findings was not fulfilled yet. Female and male students with low ability do not think algebra yet because all indicators were not fulfilled. This occurred because they still did not understand algebra concept until they could not solve Mathematics problem. Female and male students with high and medium ability who already thought algebra can solve Mathematics problem. However, female and male students with low ability still do not think algebra until they cannot solve the problem.
\end{abstract}

Keywords:

Process

Gender

Mathematics

Academic Ability

Copyright (C) 2020 (Ridha Chairunis', ${ }^{,}$Maimunah $^{2}$, Yenita Roza ${ }^{3}$ ). All Right Reserved

How to Cite: Chairunisa, R., Maimunah, M., \& Roza, Y. (2020). Proses Berpikir Aljabar Siswa SMP Ditinjau Dari Kemampuan Akademik Matematika Dan Gender. Jurnal Inspirasi Pendidikan, 10(2), 85-95.

This work is licensed under a Creative Commons Attribution-ShareAlike 4.0 International License. Allows readers to read, download, copy, distribute, print, search, or link to the full texts of its articles and allow readers to use them for any other lawful purpose. The journal hold the copyright. 


\section{Pendahuluan}

Pembelajaran matematika memiliki beberapa cara berpikir yaitu berpikir geometri (Geometri Thinking), berpikir aritmatika (Aritmatic Thinking), dan berpikir matematika salah satunya berpikir aljabar (Misbahuddin, Mustamin \& Nur, 2019). Aljabar merupakan perkembangan dari aritmatika, jika aritmatika berkaitan dengan angka sedangkan aljabar melakukan perhitungan atau operasi matematis yang melibatkan angka sekaligus penggunaan simbol-simbol sebagai bahasa untuk mengungkapkan ide-ide matematika (Dwirahayu dkk., 2019).

Berpikir aljabar merupakan proses pemecahan masalah matematika dimana dalam perhitungannya menggunakan huruf-huruf (variabel) serta melakukan aktivitas yang lebih mendalam lagi seperti mengidentifikasi masalah, menyajikan kembali informasi secara simbolis, membuat model matematika, serta menafsirkan dan menerapkan temuan matematik (Naziroh dkk., 2018). Berpikir aljabar melibatkan aktivitas berpikir dalam menganalisis suatu situasi melalui tiga aktivitas yaitu: (1) mengekstrak informasi dari situasi yang dilakukan dengan cara menganalisis situasi dengan menentukan informasi yang berguna dan tidak berguna, (2) menyajikan kembali informasi secara matematis yang disajikan dalam simbolsimbol matematis yang berupa kata, diagram, grafik, tabel, dan persamaan, dan (3) menafsirkan dan menerapkan temuan matematika, seperti mencari pemecahan untuk yang tidak diketahui, pengujian dugaan, dan mengidentifikasi hubungan fungsional untuk situasi yang sama dan situasi baru yang terkait (Rahmawati dkk., 2019). Berpikir aljabar menggunakan simbol dan alat matematika untuk menganalisis kondisi yang berbeda dengan merepresentasikan informasi secara matematis mengenai kata-kata, diagram, tabel, grafik dan persamaan dan menggunakan temuan matematika seperti menghitung nilai yang tidak diketahui, membuktikan dan menentukan hubungan antar fungsi (Ntsohi, 2013).

Proses berpikir aljabar siswa sekolah menengah pertama (SMP) masih menjadi perhatian, sebab pada siswa sekolah menengah pertama merupakan transisi dari berpikir aritmatika ke berpikir aljabar. Berdasarkan beberapa hasil penelitian bahwa kemampuan berpikir aljabar masih rendah dengan rata-rata indikator sekitar $40 \%$ dan ketika belajar aljabar siswa mulai mengalami perubahan yang signifikan dalam proses berpikir yaitu dari berpikir aritmatik menjadi berpikir aljabar (abstrak) sehingga adanya perubahan yang signifikan dalam proses berpikir tersebut membuat materi aljabar dirasa sulit oleh kebanyakan siswa sekolah menengah pertama (SMP) (Nurhayati dkk., 2017) ( Ardiansari, 2018) (Booker \& Windsor, 2010) . Jika pada penelitian sebelumnya melihat proses berpikir pada materi persamaan linier satu variabel (PLSV), pola bilangan, fungsi dan sistem persamaan linier dua variabel (SPLDV) (Wahyuniar dkk., 2018) (Radford, 2015) (Eliyani dkk., 2019) (Naziroh dkk., 2018). Pada penelitian ini akan melihat proses berpikir aljabar pada materi segi empat. Hal ini dikarenakan pada jenjang sekolah dasar (SD) siswa telah mempelajari materi Segi Empat dengan konsep aritmatika, sedangkan pada jenjang siswa sekolah menengah pertama (SMP) materi segi empat dipadukan dengan konsep aljabar dan materi segi empat merupakan salah satu materi yang menggunakan pemecahan masalah. Kemampuan berpikir aljabar paling baik dikembangkan melalui pemecahan masalah (Azizah, 2018). Berdasarkan hasil penelitian bahwa salah satu faktor yang berkontribusi terhadap perbedaan kemampuan pemecahan masalah adalah gender (Khairunnisa \& Setyaningsih, 2017). Disamping itu pembelajaran di pondok pesantren kelas dipisahkan berdasarkan gender.

Berdasarkan paparan diatas, penelitian ini bertujuan untuk mengetahui proses berpikir aljabar siswa pada materi segi empat yang ditinjau dari kemampuan matematika dan gender. Penelitian ini akan mendeskripsikan proses berpikir aljabar siswa pada materi segi empat. 
Diharapkan penelitian ini dapat dijadikan dasar untuk guru dalam mencari dan mengambil solusi yang tepat untuk meningkatkan kemampuan berpikir aljabar siswa.

\section{Metode}

Penelitian ini menggunakan jenis pendekatan deskriptif kualitatif yang akan mendeskripsikan bagaimana proses berpikir aljabar siswa sekolah menengah pertama (SMP) dalam menyelesaikan soal bangun datar segi empat. Penelitian ini dilaksanakan di kelas IX SMP Pondok Pesantren Babusalam Pekanbaru. Waktu pelaksanaan penelitian yaitu tanggal 9 Maret 2020. Teknik pengambilan sampel menggunakan teknik purposive sampling dengan tipe maximal variation purposive sampling. Sampel dikelompokkan menjadi tiga kategori yaitu kemampuan matematika tinggi, sedang, dan rendah. Pengelompokkan kemampuan tersebut berdasarkan informasi yang diberikan oleh guru mata pelajaran matematika. Sehingga subjek penelitian terdiri dari 3 siswa perempuan kemampuan tinggi, 3 siswa perempuan kemampuan sedang, 3 siswa perempuan kemampuan rendah, 3 siswa laki-laki kemampuan tinggi, 3 siswa laki-laki kemampuan sedang, dan 3 siswa laki-laki kemampuan rendah. Instrumen dalam penelitian ini dibedakan menjadi dua yaitu tes dan wawancara. Subjek yang sudah dipilih diberikan soal uraian sebanyak 3 soal mengenai bangun datar segi empat yang kemudian hasil jawaban siswa tersebut akan dianalisis. Untuk mengklarifikasikan hasi analisis jawaban siswa maka dilakukan wawancara pada siswa. Teknik keabsahan data yang digunakan dalam penelitian ini yaitu metode triangulasi. Analisis data yang dilakukan penelitian selama dan setelah pengumpulan data yaitu reduksi data, penyajian data, verifikasi data dan penarikan kesimpulan.

Adapun indikator berpikir aljabar pada penelitian ini merujuk pada pendapat Naziroh, Rahmawati, dkk dan Ntsohi yaitu seperti pada tabel berikut :

Tabel 1. Indikator Berpikir Aljabar

\begin{tabular}{ll}
\hline \multicolumn{1}{c}{ Indikator } & \multicolumn{1}{c}{ Deskriptor } \\
\hline $\begin{array}{l}\text { Mengekstrak informasi dari situasi yang } \\
\text { diberikan }\end{array}$ & $\begin{array}{l}\text { Memahami dan menulis ulang informasi } \\
\text { dengan lengkap dan tepat }\end{array}$ \\
\hline Menentukan pola dari masalah matematika & $\begin{array}{l}\text { Menggunakan strategi yang tepat dalam } \\
\text { menyelesaikan masalah. }\end{array}$ \\
& $\begin{array}{l}\text { Menggunakan aturan aljabar yang tepat } \\
\text { dalam proses menyelesaikan masalah }\end{array}$ \\
\hline $\begin{array}{l}\text { Menafsirkan dan menerapkan temuan } \\
\text { matematika }\end{array}$ & $\begin{array}{l}\text { Menerapkan nilai variabel untuk } \\
\text { menentukan solusi permasalahan }\end{array}$ \\
& $\begin{array}{l}\text { Menyimpulkan dan memeriksa kembali } \\
\text { hasil yang diperoleh }\end{array}$ \\
\hline
\end{tabular}

Siswa dikatakan berpikir aljabar jika dalam langkah pemecahan masalah menunjukkan minimal satu indikator dari berpikir aljabar (Warsitasari, 2015).

\section{Hasil dan pembahasan}

Hasil dari penelitian ini menunjukkan bahwa siswa dengan kemampuan matematika yang berbeda memiliki proses berpikir aljabar yang berbeda pula. Ini terlihat dari jawaban siswa setelah diberikan soal uraian sebanyak 3 soal. Berikut ini adalah hasil analisis proses berpikir aljabar siswa dari masing-masing kemampuan matematika dan gender :

\section{Siswa Perempuan Kemampuan Matematika Tinggi (PKMT)}

Pada soal no 1 untuk indikator mengekstrak informasi dari situasi yang diberikan, siswa PKMT sudah mampu memahami informasi yang ada pada soal terlihat dari cara siswa 
menuliskan diketahui dan ditanya secara lengkap dan tepat. Pada indikator menentukan pola dari masalah, siswa mampu menggunakan strategi yang tepat dengan menggunakan informasi yang ada pada soal serta menggunakan aturan aljabar yang tepat dalam proses penyelesaian masalah. Siswa juga mampu pada indikator menafsirkan dan menerapkan temuan yang diperoleh yaitu tampak dari siswa menerapkan nilai dari variabel yang tidak diketahui untuk melangkah pada proses pemecahan masalah. Siswa mampu dalam menyimpulkan dan memeriksa kembali hasil yang diperoleh hal ini tampak dari hasil wawancara kepada siswa PKMT, siswa mengatakan setelah memperoleh nilai $\mathrm{x}$ kemudian diuji ke keliling persegi ternyata keliling persegi A sama dengan 2 kali keliling persegi B.

Pada soal no 2 untuk indikator mengekstrak informasi dari situasi yang diberikan, siswa PKMT sudah mampu memahami informasi yang ada pada soal terlihat dari cara siswa menuliskan diketahui dan ditanya secara lengkap dan tepat. Siswa PKMT sudah mampu pada indikator menentukan pola dari masalah matematika terlihat dari cara siswa menggunakan strategi yang tepat dengan menggunakan informasi yang ada pada soal serta menggunakan aturan aljabar yang tepat dalam proses penyelesaian masalah. Siswa PKMT sudah mampu pada indikator menafsirkan dan menerapkan temuan yang diperoleh terlihat dari siswa menerapkan nilai variabel yang diperoleh untuk menyelesaikan permasalahan. Namun siswa mengalami kesalahan pada tahap akhir yaitu menentukan luas yang tidak diarsir. Siswa tidak mengalikan luas persegi yang didapat dengan 4, karena akan dibuat 4 sulaman pada kain tersebut. Dalam menentukan luas kain yang tidak di arsir yaitu mengurangkan luas persegi panjang dengan 4 kali luas persegi. Berdasarkan hasil wawancara siswa PKMT, yaitu siswa ceroboh dalam tahap akhir dimana siswa lupa mengalikan luas persegi dengan 4. Siswa mampu membuat kesimpulan dan memeriksa kembali hasil temuan yakni dari hasil wawancara kepada siswa PKMT, siswa mengatakan setelah memperoleh nilai x kemudian diuji ke keliling persegi panjang ternyata setelah diganti nilai x pada panjang dan lebar dan dimasukkan ke rumus keliling hasil yang diperoleh 120, sama dengan informasi yang ada pada soal. Meskipun hasil jawaban akhir siswa salah yang disebabkan ketidaktelitian dalam membaca informasi.

Pada soal no 3 untuk indikator mengekstrak informasi dari situasi yang diberikan, siswa PKMT sudah mampu memahami informasi yang ada pada soal terlihat dari cara siswa menuliskan diketahui dan ditanya secara lengkap dan tepat. Dalam memecahkan permasalahan yang diberikan siswa sudah mampu pada indikator menentukan pola dari masalah yang diberikan yaitu siswa mampu menggunakan strategi yang tepat dengan menggunakan informasi yang ada pada soal serta menggunakan aturan aljabar yang tepat dalam proses penyelesaian masalah. Siswa juga mampu pada indikator menafsirkan dan menerapkan temuan yang diperoleh dari proses pemecahan masalah yaitu siswa menerapkan nilai variabel yang diperoleh untuk menyelesaikan permasalahan. Siswa sudah mampu menyimpulkan dan memeriksa kembali hasil temuan yang diperoleh. Hal ini tampak dari hasil wawancara kepada siswa PKMT, siswa mengatakan setelah memperoleh nilai x pada masing-masing bangun datar kemudian diuji ke keliling jajargenjang dan keliling trapesium.

\section{Siswa Laki-laki Kemampuan Matematika Tinggi (LKMT)}

Pada soal no 1 untuk indikator mengekstrak informasi dari situasi yang diberikan, siswa LKMT sudah mampu memahami informasi yang ada pada soal terlihat dari cara menulis diketahui dan ditanya secara lengkap dan benar. Dalam memecahkan permasalahan yang diberikan siswa sudah mampu pada indikator menentukan pola dari masalah tersebut yaitu siswa LKMT mampu menggunakan strategi yang tepat dengan menggunakan informasi yang 
ada pada soal serta menggunakan aturan aljabar yang tepat dalam proses penyelesaian masalah. Pada indikator menafsirkan dan menerapkan temuan matematika, siswa laki-laki sudah mampu menerapkan nilai variabel untuk menetukan solusi permasalahan yaitu tampak dari jawaban siswa yang meenrapkan nilai variabel x yang diperoleh untuk menentukan luas persegi B. Namun pada deskriptor menyimpulkan dan memeriksa kembali, siswa LKMT tidak membuat kesimpulan dan tidak memeriksa kembali hasil temuannya meskipun penyelesain masalahnya benar. Berdasarkan hasil wawancara siswa LKMT, ketika siswa tersebut memperoleh nilai dari variabel tidak diuji ke keliling langsung melanjutkan pada tahap menentukan luas persegi B. Setelah mendapat luas persegi B siswa tidak menyimpulkan bahwa luas persegi B adalah $64 \mathrm{~cm}^{2}$. Karena siswa beranggapan telah menemukan luas persegi B. Jadi tidak membuat kesimpulan.

Pada soal no 2 untuk indikator mengekstrak informasi dari situasi yang diberikan, siswa LKMT sudah mampu memahami informasi yang ada pada soal. Namun siswa LKMT menuliskan diketahui tidak secara lengkap, siswa hanya membuat bentuk persegi panjang. Semestinya siswa menuliskan kain sulaman berbentuk persegi panjang. Berdasarakan hasil wawancara siswa LKMT, siswa mampu menyebutkan informasi yang ada pada soal dengan benar tetapi dalam membuat diketahui siswa langsung membuat bentuk bangun datar dari kain sulaman. Dalam memecahkan permasalahan yang diberikan siswa sudah mampu pada indikator menentukan pola dari masalah yang diberikan yaitu siswa mampu menggunakan strategi yang tepat dengan menggunakan informasi yang ada pada soal serta menggunakan aturan aljabar yang tepat dalam proses penyelesaian masalah. Siswa juga mampu pada indikator menafsirkan dan menerapkan temuan yang diperoleh dari proses pemecahan masalah yaitu menerapkan nilai variabel yang diperoleh untuk menyelesaikan permasalahan. Meskipun jawaban siswa tersebut benar, siswa tidak membuat kesimpulan dan tidak memeriksa kembali hasil temuannya. Berdasarkan hasil wawancara siswa LKMT, ketika siswa tersebut memperoleh nilai dari variabel tidak diuji ke keliling persegi panjang langsung melanjutkan pada tahap menentukan luas persegi panjang. Setelah mendapat luas persegi siswa melanjutkan menentukan luas 4 sulaman yang berbetuk persegi dan akhirnya menentukan luas kain yang tidak di sulam. Karena siswa beranggapan telah menemukan luas kain yang tidak disulam sehingga tidak membuat kesimpulan.

Pada soal no 3 untuk indikator mengekstrak informasi dari situasi yang diberikan, siswa LKMT sudah mampu memahami informasi yang ada pada soal. Namun siswa LKMT menuliskan diketahui tidak secara lengkap yaitu siswa tidak menulis pak anto memiliki dua kebun yang berbentuk jajar genjang dan trapesium sama kaki. Siswa langsung menuliskan bentuk jajargenjang, keliling $64 \mathrm{~m}$ dan tinggi $10 \mathrm{~m}$, bentuk trapesium, keliling $65 \mathrm{~m}$ dan tinggi 8m. Berdasarakan hasil wawancara siswa LKMT, siswa mampu menyebutkan informasi yang ada pada soal dengan benar tetapi dalam membuat diketahui siswa langsung membuat bentuk bangun datar dari kedua kebun. Dalam memecahkan permasalahan yang diberikan siswa mampu menerapkan indikator menentukan pola dari masalah yang diberikan yaitu siswa mampu menggunakan strategi yang tepat dengan menggunakan informasi yang ada pada soal serta menggunakan aturan aljabar yang tepat dalam proses penyelesaian masalah. Untuk indikator menafsirkan dan menerapkan temuan pada deskriptor menerapkan hasil temuan yakni nilai variabel $\mathrm{x}$, siswa salah memasukkan nilai variabel pada bangun jajargenjang. Siswa memasukkan nilai variabel $\mathrm{x}$ bangun trapesium ke luas jajargenjang. Berdasarkan hasil wawancara siswa LKMT, siswa mengatakan tidak teliti memasukkan nilai variabel $\mathrm{x}$ pada luas jajargenjang, nilai yang siswa masukkan pada luas jajargenjang yaitu nilai x pada bangun trapesium. Hal ini disebabkan karena siswa tidak teliti melihat nilai variabel pada kedua 
bangun datar. Siswa membuat kesimpulan yang tidak benar, karena hasil yang diperoleh siswa untuk banyak pohon pada jajar genjang salah.

\section{Siswa Perempuan Kemampuan Matematika Sedang (PKMS)}

Pada soal no 1 untuk indikator mengekstrak informasi dari situasi yang diberikan, siswa PKMS sudah mampu memahami informasi yang ada pada soal terlihat dari cara siswa menuliskan diketahui dan ditanya secara lengkap dan tepat. Dalam memecahkan permasalahan yang diberikan siswa sudah mampu pada indikator menentukan pola dari masalah tersebut yaitu siswa mampu menggunakan strategi yang tepat dengan menggunakan informasi yang ada pada soal serta menggunakan aturan aljabar yang tepat dalam proses penyelesaian masalah. Siswa juga mampu pada indikator menafsirkan dan menerapkan temuan yang diperoleh yaitu tampak dari siswa menerapkan nilai dari variabel yang tidak diketahui untuk melangkah pada proses pemecahan masalah. Memeriksa kembali hasil yang diperoleh hal ini tampak dari hasil wawancara kepada siswa PKMS, siswa mengatakan setelah memperoleh nilai $\mathrm{x}$ kemudian dimasukkan ke panjang sisi $\mathrm{A}$ dan sisi $\mathrm{B}$ kemudian masukkan ke keliling persegi.

Pada soal no 2 untuk indikator mengekstrak informasi dari situasi yang diberikan, siswa PKMS sudah mampu memahami informasi yang ada pada soal terlihat dari cara siswa menuliskan diketahui dan ditanya secara lengkap dan benar. Dalam memecahkan permasalahan yang diberikan siswa sudah mampu pada indikator menentukan pola dari masalah tersebut yaitu siswa mampu menggunakan strategi yang tepat dengan menggunakan informasi yang ada pada soal serta menggunakan aturan aljabar yang tepat dalam proses penyelesaian masalah. Siswa juga mampu pada indikator menafsirkan dan menerapkan temuan yang diperoleh dari proses pemecahan masalah yaitu menerapkan nilai variabel $\mathrm{x}$ yang diperoleh untuk menentukan luas kain yang akan disulam. Siswa juga mampu dalam menyimpulkan dan memeriksa kembali hasil yang diperoleh hal ini tampak dari hasil wawancara kepada siswa PKMS, siswa mengatakan setelah memperoleh nilai x kemudian diuji ke keliling persegi panjang ternyata setelah diganti nilai $\mathrm{x}$ pada panjang dan lebar dan dimasukkan ke rumus keliling hasil yang diperoleh 120. Sama dengan informasi yang ada pada soal.

Pada soal no 3 untuk indikator mengekstrak informasi dari situasi yang diberikan, siswa PKMS sudah mampu memahami informasi yang ada pada soal terlihat dari cara siswa menuliskan diketahui dan ditanya secara lengkap dan tepat. Dalam memecahkan permasalahan yang diberikan siswa sudah mampu pada indikator menentukan pola dari masalah tersebut yaitu siswa mampu menggunakan strategi yang tepat dengan menggunakan informasi yang ada pada soal serta menggunakan aturan aljabar yang tepat dalam proses penyelesaian masalah. Siswa juga mampu pada indikator menafsirkan dan menerapkan temuan yang diperoleh dari proses pemecahan masalah yaitu siswa menerapkan nilai variabel yang diperoleh untuk menyelesaikan permasalahan. Namun pada langkah menentukan luas jajar genjang siswa salah dalam menggunakan aturan operasi hitung yaitu siswa membagi 14 dengan 2, semestinya 14 ditambahkan dengan 3 karena berada di dalam kurung. Berdasarkan hasil wawancara, siswa PKMS memahami strategi yang dilakukan untuk memecahkan masalah yang diberikan. Siswa mengatakan karena 14 bisa dibagi 2 makanya saya bagi dengan 2, tetapi saya tidak melihat langkah sebelumnya bahwa $14+3$ diperoleh dari $(2 x+3)$ dimana $x=7$ yang seharusnya $(2 \times 7+3)$ sama dengan $14+3$ dengan hasil 17 . Siswa sudah mampu menyimpulkan meskipun salah di dalam langkah penyelesain dan memeriksa kembali hasil temuan yang diperoleh hal ini tampak dari hasil wawancara kepada siswa 
PKMS, siswa mengatakan setelah memperoleh nilai $\mathrm{x}$ pada masing-masing bangun datar kemudian diuji ke keliling jajargenjang dan keliling trapesium.

\section{Siswa Laki-laki Kemampuan Matematika Sedang (LKMS)}

Pada soal no 1 untuk indikator mengekstrak informasi dari situasi yang diberikan, siswa LKMS sudah mampu memahami informasi yang ada pada soal. Namun dalam menulis informasi, siswa laki-laki tidak menulis informasi secara jelas dan lengkap. Berdasarkan wawancara siswa LKMS, siswa mampu menyebutkan informasi yang ada pada soal yaitu siswa mengetahui panjang sisi persegi A $(3 x+7)$, panjang sisi persegi $(4 x-4)$, keliling persegi $\mathrm{A}=2$ kali keliling persegi $\mathrm{B}$. Dalam memecahkan permasalahan yang diberikan siswa sudah mampu pada indikator menentukan pola dari masalah tersebut yaitu siswa LKMS mampu menggunakan strategi yang tepat dengan menggunakan informasi yang ada pada soal serta menggunakan aturan aljabar yang tepat dalam proses penyelesaian masalah. Pada indikator menafsirkan dan menerapkan temuan matematika, siswa LKMS sudah mampu menerapkan nilai variabel untuk menetukan solusi permasalahan yaitu tampak dari jawaban siswa yang meenrapkan nilai variabel x yang diperoleh untuk menentukan luas persegi B. Namun pada deskriptor menyimpulkan dan memeriksa kembali, siswa LKMS tidak membuat kesimpulan dan tidak memeriksa kembali hasil temuannya meskipun penyelesain masalahnya benar. Berdasarkan hasil wawancara siswa LKMS, ketika siswa tersebut memperoleh nilai dari variabel tidak diuji ke keliling langsung melanjutkan pada tahap menentukan luas persegi B. Setelah mendapat luas persegi B siswa tidak menyimpulkan bahwa luas persegi B adalah 64 $\mathrm{cm}^{2}$. Karena siswa beranggapan telah menemukan luas persegi B. Jadi tidak membuat kesimpulan.

Pada soal no 2 untuk indikator mengekstrak informasi dari situasi yang diberikan, siswa LKMS sudah mampu memahami informasi yang ada pada soal. Namun dalam menulis informasi, siswa laki-laki tidak menulis informasi secara jelas dan lengkap. Berdasarkan wawancara siswa LKMS, siswa mampu menyebutkan informasi yang ada pada soal, yaitu siswa mengetahui kain sulaman berbentuk persegi panjang, panjang kain $(6 x+6)$, lebar kain $(\mathrm{x}+5)$ keliling kain $120 \mathrm{~cm}$. Dibuat sulaman bentunya persegi, panjang sisi sulaman $11 \mathrm{~cm}$, sulaman yang dibuat ada 4 buah dan yang ditanya luas kain yang tidak disulam. Dalam memecahkan soal no 2 pada indikator menentukan pola dari masalah, siswa LKMS mampu menentukan strategi dalam mencari nilai varibel $x$, tetapi salah dalam langkah menentukan solusi selanjutnya. Berdasarkan hasil wawancara siswa LKMS, siswa tersebut tidak mengetahui langkah setelah menemukan nilai x untuk menyelesaikan soal tersebut. Siswa tersebut juga mengatakan kalau soal dalam bentuk aljabar susah karena biasanya soal bangun datar menggunakan angka.

Pada soal no 3 untuk indikator mengekstrak informasi dari situasi yang diberikan, siswa LKMS sudah mampu memahami informasi yang ada pada soal. Namun dalam menulis informasi, siswa laki-laki tidak menulis informasi secara jelas dan lengkap. Berdasarkan hasil wawancara siswa LKMS, siswa tersebut mampu menyebutkan informasi yang ada pada soal namun siswa tersebut buru-buru takut kehabisan waktu. Dalam memecahkan soal no 3 pada indikator menentukan pola dari masalah, siswa LKMS mampu menentukan strategi dalam mencari nilai varibel $\mathrm{x}$ untuk masing-masing kebun meskipun terdapat kesalahan dalam operasi hitung aljabar dalam menentukan nilai x pada kebun berbentuk jajargenjang, dan salah dalam langkah menentukan solusi selanjutnya. Berdasarkan hasil wawancara siswa LKMS, siswa tersebut tidak mengetahui langkah setelah menemukan nilai $\mathrm{x}$ untuk 
meneyelesaikan soal tersebut. Siswa tersebut juga mengatakan kalau soal dalm bentuk aljabar susah karena biasanya soal bangun datar menggunakan angka.

\section{Siswa Perempuan Kemampuan Matematika Rendah (PKMR)}

Pada soal no 1 untuk indikator mengekstrak informasi dari situasi yang diberikan siswa, PKMR belum memahami informasi yang ada pada soal. Hal ini tampak dari hasil wawancara siswa PKMR, siswa bingung maksud panjang sisi persegi A (3x-7), panjang sisi persegi $\mathrm{B}$ $(4 \mathrm{x}-4)$ dan keliling persegi A sama dengan 2 kali keliling persegi B. Dalam memecahkan soal no 1 pada indikator menentukan pola dari masalah, siswa belum mampu menggunakan strategi yang tepat. Hal ini tampak dari jawaban siswa dalam menentukan nilai variabel x, siswa salah dalam menggunakan aturan aljabar yaitu siswa menambahkan $12 \mathrm{x}+28$. Berdasarkan hasil wawancara siswa PKMR, siswa mengatakan tidak paham jika menyangkut huruf-huruf (variabel) dan tidak tahu bagaimana menyelesaikan soal tersebut. Dari jawaban siswa tersebut, siswa hanya menentukan nilai variabel $\mathrm{x}$ dan tidak melangkah untuk menentukan luas persegi $\mathrm{B}$.

Pada soal no 2 untuk indikator mengekstrak informasi dari situasi yang diberikan, siswa PKMR belum memahami informasi yang ada pada soal terlihat dari hasil jawaban siswa, siswa tidak menulis informasi secara lengkap. Selain itu tampak dari hasil wawancara siswa PKMR, siswa bingung maksud panjang sisi persegi kain $(6 x+6)$, lebar kain $(x+5)$ dan keliling kain 120. Dalam memecahkan soal no 2 pada indikator menentukan pola dari masalah, siswa belum mampu menggunakan strategi yang tepat. Hal ini tampak dari jawaban siswa dalam menentukan nilai variabel $\mathrm{x}$, siswa salah dalam menggunakan aturan aljabar yaitu siswa mengalikan 6x dengan $\mathrm{x}$ dan 6 dikali 5 semestinya karena pada langkah tersebut kita menggunakan aturan operasi penjumlahan $6 x+x$ dan $6+5$. Berdasarkan hasil wawancara siswa PKMR, siswa mengatakan tidak paham jika menyangkut huruf-huruf (variabel) dan tidak tahu bagaimana menyelesaikan soal tersebut. Dari jawaban siswa tersebut, siswa hanya menentukan nilai variabel $\mathrm{x}$ dan tidak melangkah untuk menentukan luas kain yang berbentuk persegi panjang, tidak menentukan luas 4 sulaman serta tidak menentukan luas kain yang tidak di sulam.

Pada soal no 3 untuk indikator mengekstrak informasi dari situasi yang diberikan siswa, siswa PKMR belum memahami informasi yang ada pada soal terlihat dari hasil jawaban siswa, siswa tidak menulis informasi secara lengkap. Dalam memecahkan soal no 3 pada indikator menentukan pola dari masalah, siswa tidak menggunakan strategi yang tepat dalam menyelesaikan soal terlihat dari siswa tidak menggunakan informasi aljabar yang tertera dalam soal. Siswa juga tidak membuat kesimpulan yang benar dan tidak memeriksa kmebali hasil temuan. Berdasarkan hasil wawancara siswa PKMR, siswa tidak tahu harus menggunakan cara apa dalam menyelesaiakan soal no 3 karena tidak tahu jika menggunakan huruf-huruf (variabel) dan tidak paham soal cerita bangun datar.

\section{Siswa Laki-laki Kemampuan Matematika Rendah (LKMR)}

Pada soal no 1 untuk indikator mengekstrak informasi dari situasi yang diberikan siswa, siswa LKMR belum mampu memahami informasi yang ada pada soal. Hal ini terlihat dari jawaban siswa yang tidak menulis diketahui dan ditanya. Dalam memecahkan soal no 1 pada indikator menentukan pola dari masalah, siswa tidak menggunakan strategi yang benar dan tidak menggunakan aturan aljabar yang benar. Hali ini tampak dari hasil jawaban siswa, yang tidak menggunakan informasi yang ada pada soal yaitu siswa tidak menggunakan informasi 
keliling persegi $\mathrm{A}=2$ kali keliling persegi $\mathrm{B}$ untuk menentukan nilai variabel $\mathrm{x}$. Siswa juga tidak menerapkan hasil temuan dan memeriksa kembali hasil temuan, hal ini tampakkarena siswa tidak mencari nilai dari variabel $\mathrm{x}$. Berdasarkan hasil wawancara siswa LKMR, siswa tidak mengerti jika diberikan soal yang mengandung huruf didalamnya, menurut penuturan siswa kalau sudah barbaur aljabar siswa tidak paham.

Pada soal no 2 untuk indikator mengekstrak informasi dari situasi yang diberikan siswa LKMR belum mampu memahami informasi yang ada pada soal. Hal ini terlihat dari jawaban siswa yang tidak menulis diketahui dan ditanya. Dalam memecahkan soal no 2 pada indikator menentukan pola dari masalah, siswa tidak menggunakan strategi yang benar dan tidak menggunakan aturan aljabar yang benar. Hali ini tampak dari hasil jawaban siswa, yang tidak menggunakan informasi yang ada pada soal yaitu siswa tidak menggunakan keliling kain berbentk persegipanjang untuk menentukan nilai variabel x. Siswa juga tidak menerapkan hasil temuan dan memeriksa kembali hasil temuan, hal ini tampak karena siswa tidak mencari nilai dari variabel x. Berdasarkan hasil wawancara siswa LKMR, siswa tidak mengerti jika diberikan soal yang mengandung huruf didalamnya, menurut penuturan siswa kalau sudah barbaur aljabar siswa tidak paham.

Pada soal No 3 siswa laki-laki KMR belum mampu memahami informasi yang ada pada soal. Hal ini terlihat dari jawaban siswa yang tidak menulis diketahui dan ditanya. Dalam menyelesaikan permasalahan siswa juga tidak menggunakan strategi yang benar dan tidak menggunakan aturan aljabar yang benar. Hali ini tampak dari hasil jawaban siswa, yang tidak menggunakan informasi yang ada pada soal yaitu siswa tidak menggunakan keliling masingmasing bangun datar untuk menentukan nilai variabel x. Siswa juga tidak menerapkan hasil temuan dan memeriksa kembali hasil temuan, hal ini tampak karena siswa tidak mencari nilai dari variabel $\mathrm{x}$. Berdasarkan hasil wawancara siswa L6, siswa tidak mengerti jika diberikan soal yang mengandung huruf didalamnya, menurut penuturan siswa kalau sudah barbaur aljabar siswa tidak paham. Hal ini sejalan dengan penelitian berpikir aljabar sebelumnya yakni siswa kemampuan rendah sulit dalam menganalisis permasalahan sehingga tidak mendapatkan solusi yang benar dalam menyelesaikan masalah (Saputro \& Mampouw, 2018).

Berdasarkan hasil paparan diatas, siswa perempuan KMT sudah berpikir aljabar dalam menyelesaikan permasalahan yang diberikan hal ini tampak dari ketiga indikator bepikir aljabar sudah terpenuhi. Namun masih terdapat kecerobohan didalam membaca informasi sehingga menimbulkan kesalahan pada tahap akhir menyelesaikan soal no 2. Siswa laki-laki KMT sudah berpikir aljabar dalam menyelesaikan permasalahan yang diberikan yaitu indikator mengekstrak informasi dari situasi yang diberikan dan menentukan pola dari masalah matematika sudah terpenuhi. Untuk indikator ketiga memeriksa hasil temuan, siswa laki-laki tidak memeriksa hasil temuan karena menganggap setelah memperoleh nilai variabel langsung melangkah pada tahap penyelesaian masalah selanjutnya. Siswa laki-laki juga melakukan kecerobohan di dalam menerapkan hasil temuan pada soal no 3.

Siswa perempuan KMS sudah berpikir aljabar dalam menyelesaikan permasalahan yang diberikan hal ini tampak dari ketiga indikator bepikir aljabar sudah terpenuhi. Namun masih terdapat kecerobohan didalam menggunakan aturan operasi bilangan pada soal no 3. Siswa laki-laki KMS sudah mulai berpikir aljabar, hal ini tampak dari indikator mengekstrak informasi dari situasi yang sudah terpenuhi dan indikator menentukan pola dari masalah matematika dengan deskripsi menentukan strategi memecahkan masalah, siswa laki - laki hanya mampu sampai menentukan nilai variabel $\mathrm{x}$ tetapi tidak bisa melangkah pada 
penyelesaian selanjutnya. Untuk indikator ketiga yaitu memeriksa hasil temuan belum terpenuhi. Siswa dikatakan berpikir aljabar jika dalam langkah pemecahan masalah menunjukkan minimal satu indikator dari berpikir aljabar (Warsitasari, 2015).

Siswa perempuan KMR dan laki-laki KMR belum berpikir aljabar karena ketiga indikator tidak terpenuhi, penyebab dari situasi ini yaitu karena siswa tidak memahami konsep aljabar. Dalam menyelesaikan 3 soal uraian tersebut, siswa tidak mampu menyelesaikan soal dengan benar. Berdasarkan hasil penelitian sebelumnya, kemampuan berpikir aljabar subjek kelompok tinggi dalam menyelesaikan masalah cenderung baik, kemampuan berpikir aljabar subjek kelompok sedang dalam menyelesaikan masalah cenderung baik, dan kemampuan berpikir aljabar subjek kelompok rendah dalam menyeelsaikan masalah cenderung kurang (Azizah, 2018)

Dampak dari penelitian ini yaitu mengetahui proses berpikir aljabar siswa berdampak dalam kemampuan pemecahan masalah siswa, dimana jika siswa memiliki kemampuan berpikir aljabar maka siswa mampu dalam memecahan masalah yang diberikan. Setelah mengetahui kemampuan berpikir aljabar siswa dalam memecahkan masalah, guru mampu menciptakan solusi yang tepat dalam meningkatkan kemampuan berpikir aljabar siswa terutama dalam mengarahkan transisi berpikir siswa dari berpikir aritmatik menuju berpikir aljabar. Untuk penelitian selanjutnya, bisa mengulas lebih dalam mengenai penyebab rendahnya berpikir aljabar dari kemampuan matematika sedang dan rendah serta menemukan solusi yang tepat untuk meningkatkan kemampuan berpikir aljabar.

\section{Simpulan}

Hasil penelitian tentang berpikir aljabar siswa sekolah menengah pertama (SMP) materi segi empat yang ditinjau dari kemampuan akademik matematika dan gender yaitu siswa perempuan KMT sudah berpikir aljabar dimana seluruh indikator berpikir aljabar terpenuhi. Siswa laki-laki KMT sudah berpikir aljabar namun pada indikator ketiga yaitu menyimpulkan dan memeriksa kembali belum terpenuhi. Siswa perempuan KMS sudah berpikir aljabar dimana seluruh indikator berpikir aljabar terpenuhi. Siswa laki-laki KMS sudah mulai berpikir aljabar, pada indikator berpikir aljabar pertama yaitu mengekstrak informasi dari situasi yang diberikan perlu diperhatikan kembali karena dalam menuliskan informasi masih belum secara lengkap. Pada indikator berpikir aljabar kedua yaitu menentukan pola dari masalah matematika, sudah bisa menentukan strategi dalam mencari nilai variabel dan menggunakan aturan aljabar yang benar. Untuk indikator aljabar ketiga yaitu menafsirkan dan menerapkan temuan matematika, siswa belum mampu menerapkan temuan untuk melangkah pada penyelesaian. Untuk indikator ketiga ini perlu diperhatikan lagi di dalam pembelajaran matematika. Siswa perempuan KMR dan siswa laki-laki KMR belum berpikir aljabar karena ketiga indikator belum terpenuhi. Penyebab dari siswa belum berpikir aljabar ini adalah siswa tidak memahami konsep aljabar sehingga dalam memecahkan masalah siswa tidak mampu. Siswa perempuan dan laki-laki kemampuan tinggi dan sedang yang sudah berpikir aljabar mampu dalam memecahkan masalah matematika. Namun Siswa perempuan dan laki-laki kemampuan rendah belum berpikir aljabar sehingga belum mampu menyelesaikan masalah.

Bagi guru hendaknya lebih menenkankan konsep aljabar sehingga siswa mampu menyelesaikan berbagi permasalahan dalam berbagai materi matematika. Bagi peneliti selanjutnya diharapkan dapat mengulas lebih lengkap penyebab kemampuan berpikir aljabar 
pada kemampuan matematika sedang dan rendah dan dapat menemukan solusi yang tepat untuk meningkatkan kemampuan berpikir aljabar.

\section{Referensi}

Ardiansari, L. (2018). Pra-Aljabar : Langkah Baru Mengajar Aljabar Awal, PROXIMAL: Jurnal Penelitian dan Pendidikan Matematika, 32-44.

Azizah, I. R. (2018). Kemampuan Berpikir Aljabar Siswa Dalam menyelesaikan Masalah Bangun Datar Segiempat, Artikel Skripsi: Universitas Nusantara PGRI Kediri, 136-144.

Booker, G., \& Windsor, W. (2010). Developing Algebraic Thinking: Using problem-solving to build from number and geometry in the primary school to the ideas that underpin algebra in high school and beyond. Procedia Social and Behavioral Sciences, 8, 411419.

Dwirahayu, G., Halpiani, M., \& Kustiawati, D.(2019). Peningkatan Kemampuan Berpikir Aljabar Melalui Pembelajaran Schema-Based Instruction Dengan Strategi FOPS. FIBONACCI: Jurnal Pendidikan Matematika dan Matematika 5(2), 105-116.

Eliyani, R., Deniyanti, P., \& Sari, P.(2017). Mengembangkan Kemampuan Berpikir Aljabar Pada Materi Fungsi Dengan Pendekatan PMRI Di SMP Negeri 7 Jakarta. Jurnal Riset Pembelajaran Matematika Dan Sains, 19-28.

Khairunnisa, R., \& Setyaningsih, N. (2017). Analisis Metakognisi Siswa Dalam Pemecahan Masalah Aritmatika Sosial Ditinjau Dari Perbedaan Gender. Prosiding KNPMP II (pp.465-474). Surakarta: Universitas Muhammadiyah Surakarta.

Misbahuddin., Mustamin, S. H., \& Nur, F. (2019). Analisis Keterampilan Berpikir Aljabar Siswa Kelas VIII MTs. Asma : Jurnal of Islamic Education 1(2), 76-88.

Naziroh, I. A., Yudianto, E., \& Pratama, R. (2018). Proses Berpikir Aljabar Siswa Dalam Memecahkan Permasalahan Matematika Berdasarkan Kemampuan Aljabar Dan Gender. Kadikma, 136-144.

Ntšohi, M. M. E. (2013). Investigating Teaching And Learning Of Grade 9 Algebra Through Excel Spreadsheets: A Mixed-Methods Case Study For Lesotho. 279.

Nurhayati, D.M., Herman, T., \& Suhendra, S. (2017). Analysis of Secondary School Students' Algebraic Thinking and Math-Talk Learning Community to Help Students Learn. International Conference on Mathematics and Science Education (ICMScE), 895, $1-7$.

Radford, L. (2015). Early Algebraic Thinking: Epistemological, Semiotic, and Developmental Issues. In S. J. Cho (Ed.), The Proceedings of the 12th International Congress on Mathematical Education (pp. 209-227). Springer International Publishing.

Rahmawati, A. W., Juniati, D., \& Lukito, A. (2019). Algebraic Thinking Profiles of Junior High Schools' Pupil in Mathematics Problem Solving. International Journal of Trends in Mathematics Education Research 2(4), 202-206.

Saputro, G. B., \& Mampouw, H. L. (2018).Profil Kemampuan Berpikir Aljabar Siswa SMP Pada Materi Persamaan Linier Satu Variabel Ditinjau Dari Perbedaan Gender. Jurnal Numeracy, 5(1), 77-90.

Wahyuniar, L. S., Shofia, N., \& Rochana, S. (2018). Proses Berpikir Aljabar Siswa MTs Kelas VIII Menurut Taksonomi Solo Ditinjau Dari Perbedaan Gender. AKSIOMA: Jurnal Program Studi Pendidikan Matematika, 7(2), 275-282.

Warsitasari, W. D. (2015). Berpikir Aljabar Dalam Pemecahan Masalah Matematika. APOTEMA : Jurnal Program Studi Pendidikan Matematika, 1(1), 1-17. 